\section{Ti gange Lévinas}

Emmanuel Lévinas, Fæ-nomenologi og etik, Udvalg, oversættelse og indledning ved Michael Rasmussen, Gyldendal, København 2002, 224 sider, $250 \mathrm{kr}$.

Lévinas (1906-1995) er med god grund også i Danmark ved at blive en af de helt store tænkere fra det 20. århundrede. Efter at hans hovedværk Totalitet og uendelighed (1996) og samtalebogen Etik og uendelighed (1995) er oversat, og der er udgivet et par bøger om forfatterskabet, er der nu også udgivet en større samling artikler på dansk - i alt ti styk spændende fra 1934 til 1987. Det kan tilføjes, at det faktisk var nærværende tidsskrift, der oversatte den første artikel af Lévinas i 1989 (Slagmark nr. 14) og nogle år senere også bragte artiklen "Kierkegaard. Eksistens og etik" i Denne slyngelagtige eftertid. Tekster om Soren Kierkegaard (Slagmarks Skyttegravsserie 1995).

Artiklerne i Fænomenologi og etik bærer alle præg af at være "lévinas'ske", dvs. kredsende omkring etik, ansigtet, næsten m.v. samtidig med, at de fokuserer og polemiserer i forskellige retninger. Man kan altså som helhed gå til bogen på mange måder. For det første kan man læse alle artiklerne ud fra en overordnet intention om at opstøve, hvad Lévinas egentlig mener. For det andet kan artiklerne læses med henblik på at afklare specifikke udviklinger i forfatterskabet. For det tredje, og ikke mindst, kan bogen læses ud fra en almen interesse i filosofi og teologi - f.eks. med særligt henblik på at få et mere differentieret forhold til fænomenologi og etik - fordi der direkte $o g$ indirekte trækkes på og polemiseres imod tænkere som Descartes, Hegel, Husserl, Heidegger, Buber og Derrida. Endelig kan man for det fjerde også vælge at læse bogen mere eller mindre på tværs af artiklerne for at blive klogere på et bestemt tema, eksempelvis retfærdighed, frihed eller erkendelsesteori og bevidsthed. Sidstnævnte er muligt, da Lévinas hele tiden har mange bolde i luften. Jeg vil, som en mangfoldig appetitvækker, i det følgende kort skitsere eller snarere antyde og åbne op for indholdet i de ti artikler.

1. "Underskrift" er en form for selvanmeldelse, hvor han redegør for sine teoretiske inspirationskilder (Husserl, Heidegger m.fl.) og via sin forståelse af tiden og næsten efterhånden bevæger sig over i en omtale af sine egne grundbegreber: ansigtet, den anden, det uendelige og det etiske.

2. "Interview med Lévinas" beskæftiger sig, med afsæt i ansigtet, med sprog, andethed, retfærdighed, væren og kærlighed - alt sammen med henblik på at perspektivere etikken, der anskues religionsfilosofisk: Mennesket er som eksisterende i conatus essendi (s. 50, 54), dvs. styret af selvopholdelsesdriften, af 
bestræbelsen på at eksistere (forstået som et ontologisk princip). Med ansigtets tilsynekomst begrænses conatus essendi. Det er ikke en rationel grænse: At fortolke ansigtet fordrer, at man tænker det i etiske termer. Det gør, at ansigtet såvel som Gud ikke er en kraft, der ville sikre, at man gjorde, hvad der blev krævet. Ansigtet og Gud er derimod en øvrighed (s. 43, 54), der ikke gør noget, men sætter en budets etik, som man modydelsesløst kan lytte til, og det er nåden: "Forestillingen om ansigtet er forestillingen om modydelsesløs kærlighed, budet om modydelsesløs handling" (s. 56). Løbende diskuteres også her Lévinas' forhold til hhv. jødisk og græsk tænkning, og der spørges til moralens muligheder efter Auschwitz.

3. "Nogle refleksioner over hitlerismens filosofi" vurderer ikke nazismen som en galskabens filosofi, men ser på, hvordan hitlerismen formår at vække de elementære følelser, og det gør den filosofisk interessant, fordi det siger noget om den urindstilling, en sjæl har over for sit liv og skæbne. Hitlerismens filosofi problematiserer simpelthen selve de principper, der gælder for en civilisation. Her læser Lévinas på fascinerende vis jødedommen som et brud med den græske moira. Kristendommen bebuder muligheden for definitivt at begynde på ny, hvilket muliggør friheden $i$ al sin fylde, som gør, at mennesket hvert øjeblik kan "...genvinde den nøgenhed, det besad i skabelsens første dage" (s. 65). Hermed er der tale om en uendelig frihed, hvor ingen bindinger er definitive. Med filosofisk og religiøst afsæt $i$ frihedens muligheder trækker Lévinas en tråd frem til de sidste århundreders liberalisme, der trods alskens ulykker har bevaret et væsentligt element heraf: fornuftens suveræne frihed. Marxismen synes derimod at hævde, at menneskets ånd ikke er ren frihed, for den er prisgivet de materielle behov. Det er dog først, idet tænkningen accepterer, at den situation som mennesket er fastnaglet til, ikke er tilføjet mennesket, men udgør selve dets værensgrund, at de egentlige problemer opstår. Det hænger sammen med erfaringen af kroppen, der hidtil har været en forhindring, men nu bliver det identitetsskabende. Det biologiske bliver åndslivets hjerte, som vi er lænket til. Det er i alt dette, at det germanske menneskeideal træder frem som et løfte om oprigtighed og autenticitet, hvor mennesket allerede på forhånd er forbundet med nogle sandheder: "...ligesom det ved sin fødsel er forbundet med alle dem, det deler blod med. Det kan ikke længere indsætte ideen i et spil (...) Som lænket til sin krop ser mennesket sig selv blive nægtet evnen til at undslippe sig selv" (s. 74). Her bliver selve menneskets menneskelighed stridsemnet.

4. "Heidegger, Gagarin og vi" er, som titlen antyder, skrevet efter at Gagarin som den første bevægede sig hele vejen rundt om jorden, og hermed forlader vores jordiske horisont. Det rejser spørgsmålet, 
hvad teknologien formår. Her viser Lévinas sig som en ikke-refleksagtigt teknologiforskrækket tænker, hvilket efter hans mening blot ville føre til noget andet skidt, og derfor bryder han med Heideggers doktrin, om det menneskelige væsens rodfæstelse i hvad han kalder Stedet og hans desillusionerende teknikforståelse. Provokerende siger Lévinas, at jødedommen ligesom teknikken har afmystificeret universet, men den har opdaget noget andet: "...mennesket $\mathrm{i}$ dets ansigts nøgenhed" (s. 82).

5. "Martin Buber og erkendelsesteorien" er især på de første sider et skarpt og spændende livtag med erkendelsesteorien. Artiklen bevæger sig via Husserl og Heideggers opløsning af subjekt-objekt problemet frem til en udførlig vurdering af Martin Bubers Jeg-Du filosofi, der ikke er et møde mellem to subjekter, men begivenhed: "Mellem-beggeto'et', intervallet mellem Jeg og Du, zwischen'et, er det sted, hvor selve værens værk udøves" (s. 92). Sluttelig har Lévinas nogle indvendinger mod Buber, der måske også kan rettes mod Lévinas selv, idet han siger, at Buber med stor skarpsindighed har omtalt Jeg-Du relationen, men: "Mennesket er ikke blot afstandens og mødets kategori, det er også et væsen for sig selv. Det fuldbyrder denne isolering i en subjektiveringsproces, der ikke blot er et tilbagestød fra ordet Du" (s. 108). Jeg antyder, at dele af denne kritik også kunne rettes imod Lévinas selv og alle andre fænomenologisk orienterede tænkere, fordi de er alt for optaget af konstitutionsprocesser og af at slå subjektet ihjel, i stedet for at se i øjnene, at det faktisk har konsekvenser, når et subjekt fødes og begynder at sparke igen. Men det er, hvad dette angår, måske præcis her Lévinas adskiller sig fra fænomenologien!

6. "Transcendens og højde". Her siges det meget direkte, hvad den anden formår: "...han udstiller sig blottet for mordets totale negation, men forbyder det ved sine forsvarsløse øjnes oprindelige sprog" (s. 112). Det er det absolut andet, og dette åbner ifølge Lévinas op for uendeligheden, der således bliver mere basal end selv ontologien. Det er den anden, et ansigt, der uendeligt overstiger erkendelsens mål og åbner højdens dimension, netop fordi den anden intet har tilfælles med mig. Igen: "Når den anden, i og med sin nøgenhed og sine forsvarsløse øjnes blottethed, forbyder mig mordet og lammer min heftige frihed" (s. 120). Den anden skal "forstås" i.f.t. højde og uendelighed. Højden skal antyde, at et menneskes ansvar i.f.t. næsten, i ansigtet, opløftes og anråbes højt oppe fra: "Den absolut andens epifani er ansigt, hvor den anden anråber mig og befaler i og med sin nøgenhed, i og med sin blottethed. Han anråber mig ved sin ydmyghed og sin højde" (s. 122). Derfor er det at være et jeg samtidig ensbetydende med ikke at kunne unddrage sig ansvaret. At være et jeg, "...denne selvhedens 
stød fremad i væren fuldbyrder sig som en opsvulmen af ansvar" (s. 122), hvorved jeg'et bliver samhørigt med ikke-jeg'et, som om hele den andens skæbne var i ens hænder. Jeg'et begynder ifølge Lévinas netop her at sparke igen: "Jeg'ets eneståendehed er dette, at ingen kan svare $i$ dets sted" (s. 123). Uendelighedens ansvar turde hermed være indlysende. Den anden indebærer et ikke-assimilerbart overskud, og derfor kalder Lévinas den relation, der knytter jeg'et til næsten, for uendelighedsideen.

7. "Om enerens eneståendehed" vender tilbage til tidligere omtalte conatus essendi, bestræbelsen efter at være i sin væren, som sætter den enkelte $\mathrm{i}$ modsætning til de andre. Her anskuer Lévinas overvindelsen af conatus essendi i et større perspektiv. Historisk ser han individernes fornuftsandheder, der bliver til ideale sandheder, og hermed åbner sig for den menneskelige fred med udgangspunkt i stat, institutioner og politik som én vej. Hans egen etiske vej tager afsæt i budet: "Du må ikke slå ihjel!", hvorved den enkelte er udvalgt og unik og står "...til ansvar for døden og følgelig for næstens liv" (s. 138). Men selv om individets ret på den måde finder sin oprindelige betydning i den anden, mener Lévinas ikke, at han miskender det politiske, for ansvaret udvides og retfærdighedens time opstår, som f.eks. fordrer og grundlægger staten.

8. "Om meningens betyden". Beskæftiger sig i forlængelse af en kritisk Heidegger-læsning med yderligere at positionere ansigtets ansvar: "Ansigtet er betyden af det hinsidige (...) Ansigtet er ene om at oversætte transcendensen (...) ansigtets epifani, hvor et andet krav end ontologiernes er i færd med at få betydning" (s. 151). Meninger er af moralsk oprindelse, og de kan ikke reduceres til ontologi, da ansigtet og ansvaret er det egentlig meningsgivende. Socialitet leder således ikke tilbage til ontologi, men til etik.

9. "Refleksioner over den fænomenologiske 'teknik"' er i store stræk en tekstnær læsning af Husserls fænomenologi, men undervejs tilføjet Lévinas' egne perspektiveringer. Hans refleksioner angår, som han selv siger: "...uden nogen som helst systematisk hensigt, begreberne beskrivelse, intentionalitet, sanselighed og subjektivitet" (s. 155). Især hans overvejelser over sanselighed og subjektivitet og deres sammenfald (s. 165ff) er tankevækkende: "Sanseligheden gør, at ideernes 'evighed' henviser til et hoved, der tænker, til et subjekt der er tidsligt til stede" (s. 169). Spændende er også de metafysik åbnende overvejelser hen $\mathrm{i}$ mod slutningen: "Subjektet er altid en transcendens i immanensen: Det falder ikke sammen med den arv, som dets eksistens er" (s. 170). Det fænomenologiske jeg "...kan bryde og kan som følge deraf tale".

10. "Sprog og nærhed" tager afsæt i et forsøg på at bestemme hvad sprog er, og artiklen viser på hvilken måde 
sproget kan fortolkes som den vej, væren vælger for at vise sig, og på en meget kompliceret måde hvordan bl.a. intentionalitet, tid og bevidsthed spiller ind. As usual glider det over i hans etik med ansigtet som force, $i$ denne forbindelse med særlig vægt på nærhedsproblematikken hinsides intentionaliteten. Også her optræder den anden som en besættelse hos Lévinas, men da nærhed netop også en besættelse, som vi ikke kan plukke på tingenes overflade, lyder det: "Ansvaret som besættelse er nærhed, som et slægtskab, et bånd forud for enhver valgt forbindelse" (s. 205).

Gud har ikke været meget omtalt i denne fragmentariske gennemgang af de ti artikler, men der afsluttes faktisk med nogle overvejelser over, hvad ordene siger, hvad det første ord siger: "Den første sigen overstiger sine egne kræfter og sin egen grund (...) Denne første sigen er nok blot et ord. Men det er Gud" (s. 210f). Cirklen er sluttet: Det, Lévinas blot siger, er, at Gud afkræver os et svar gennem næstens ansigt. Det er et spørgsmål om ansvarlighed.

Nået til vejs ende skal det sluttelig blot siges, at der er tale om et særdeles godt og ikke mindst systematisk arbejde af udgiveren og oversætteren Michael Rasmussen, der har sammensat (og i noterne givet gode kommentarer til) teksterne i en rækkefølge, som gør det muligt at forstå dem - den sidste halvdel af artiklerne ville for den ukyndige være helt uforståelige uden den første halvdel. Mi- chael Rasmussen har også skrevet en glimrende indledning, hvorfra jeg kun kan tilslutte mig ordene (s. 27) om, at man vinder ved bare at forholde sig til Lévinas' ræsonnementer.

\section{Ole Morsing}

\section{Tørre tæsk til kunst- historikerne}

Hans Dam Christensen, Forskydningens Kunst - Kritiske bidrag til kunsthistoriens historie, Multivers, København 2001, 382 sider

Forskydningens Kunst er - efter denne anmelders opfattelse - lidt af en begivenhed i den institutionaliserede danske kunstverden. Skulle læseren af denne anmeldelse interessere sig blot et minimum for æstetik, kunst og kunsthistorie kan bogen anbefales på det varmeste. Her er nemlig faglige smæk og tørre tæsk til den traditionelle del af kunsthistoriefaget der af forfatteren rubriceres som 'normalkunsthistorien' eller - mere nedladende udtrykt - 'den gamle kunsthistorie'. Hvad er da 'den gamle kunsthistorie'? Svaret kræver en lille institutionshistorisk udredning. Sammenlignet med andre fag på dansk humaniora er det karakteristisk for kunsthistoriedisciplinen, at den har arbejdet - og til dels stadig arbejder 